\title{
Economic efficiency justification of construction and operation of electric filling stations
}

\author{
Elena Rakhmatullina ${ }^{1 *[0000-0002-2368-9694]}$, Elvira Shagiakhmetova ${ }^{1[0000-0002-0475-4374]}$, \\ Vera Kruchinina ${ }^{2[0000-0002-0559-3605]}$, and Olesya Bannova ${ }^{3[0000-0001-6973-3286]}$ \\ ${ }^{1}$ Kazan State University of Architecture and Engineering 420043, Kazan, Russia \\ ${ }^{2}$ Surgut State University 628412, Surgut, Russia \\ ${ }^{3}$ St. Petersburg state electrotechnical University 197022, St. Petersburg, Russia
}

\begin{abstract}
The number of road vehicles is growing every year. At the same time, the negative impact of cars on the environment is increasing. For many countries, the environmental problem is already coming to the fore and opens up various ways to solve it. One of these ways could be the transition to electric vehicles running on environmentally friendly energy. In many countries, the transition to electric vehicles as an environmentally friendly mode of transport is adopted at the state level, through additional incentive systems and benefits. The spread of electric vehicles in Russia is not very active. One of the reasons is the lack of the necessary infrastructure charging stations. The purpose of this research is to substantiate the economic efficiency of the construction and operation of an electric filling station (charging station). When performing the calculations, the methods of statistical analysis, the method of calculating the net present value of the project (NPV), the graphical method of presenting the final results of the study were used. Calculations showed that the net present value of the project for the construction and operation of the electric filling station will be 181952571 rubles during 9 years of operation with an annual energy consumption of $2073600 \mathrm{kWh}$. This research is of the greatest interest to private and public investors, as it is based on both environmental component and economic efficiency.
\end{abstract}

Keywords. Construction, electric vehicles, electric transport, efficiency, NPV, project management.

\section{Introduction}

The construction of electric filling stations is periodically studied using different sources from countries around the world because the popularity of electric vehicles is now constantly growing. According to authors such as Kenan Degirmenci, Michael H. Breitner [1], electric vehicles can help reduce greenhouse gas emissions, and the environmental component here far exceeds the price characteristics of this type of transport. According to the authors of Avi Chaim Mersky, Frances Sprei, Constantine Samaras, Zhen (Sean) Qian [2], in Norway, the transition to electrified personal transport is stimulated at the state level in terms of tax

*Corresponding author: rahmat_es@bk.ru 
benefits, exemption from tolls, and other incentives, since the environmental benefit is the highest priority.

According to Jie Yang, Jing Dong, Liang Hu [3], the transition to electric vehicles of entire taxi fleets in many Chinese cities can be very effective, or, as Riccardo Iacobucci, Benjamin McLellan, Tetsuo Tezuka testify, it is advisable to switch to electric vehicles the car sharing system in Japan [4]. However, in both cases, it is required to correctly position the charging stations in terms of location and distance. They will increase the economic efficiency of car sharing and taxi companies. The proliferation of electric vehicles in Italy, from the point of view of solving the problem of environmental pollution, is studied by such authors as Guido Ala, Gabriella Di Filippo, Fabio Viola, Graziella Giglia, Antonino Imburgia, Pietro Romano, Vincenzo Castiglia, Filippo Pellitteri, Giuseppe Schettino and Rosario Miceli [5].

Today, various companies around the world are concentrating their efforts on the development of electric vehicles due to the rise in prices of petroleum products. Moreover, the relevance of electric vehicles is that they reduce the harmful effects of transport on nature, and their use is a step forward towards a greener lifestyle.

The environmental benefits of electric vehicles are already being evaluated in the United States. At the moment, a lot of attention is paid to the social side of the issue, namely, the possibility of including all population groups in access to the charging infrastructure through the device of public charging stations [6]. Also, attention is paid to the economic component in terms of estimating the total system costs [7].

Many foreign authors consider the development of electric vehicles from a broad point of view in terms of the economic and environmental component to identify market opportunities for electric vehicles in the context of their use, the device of charging stations, and in terms of solving the energy crisis and environmental problems [8-14].

Electric vehicles have established themselves as a viable alternative to traditional transportation over the past few years. It is no longer just about individual models of an experimental nature. It is time to talk about the beginning of the creation of global infrastructure, the attitude towards which is still being formed. In early 2020, electric vehicles began to be seen as a new era for road transport, but the pandemic has adjusted these plans but did not cancel them altogether.

In Russia, this type of transport is not yet so well known, but there are already certain expectations associated with it. The article by such authors as Karol Tucki, Olga Orynycz, Antoni Swi'c, and Mateusz Mitoraj-Wojtanek analyzes the dynamics of the development of the electromobility sector in Russia [15]. In Russia, the release of domestic electric vehicles is expected in 2021: KAMA-1, Monarch., Zetta, GAZelle e-NN. The global electric vehicle market expects: Volkswagen ID3, Volvo XC Recharge P8, Nissan Ariya, and such modernized novelties as Nissan Leaf, Tesla Model S, Tesla Model X, Tesla Model, Audi ETron, have already proven their reputation for reliability in earlier versions.

An analysis of the array of publications, where along with the opinions of experts were the opinions of drivers, showed that ordinary drivers are interested in getting to know this type of transport better but in the presence of a regulated service network and developed infrastructure of gas stations and service stations. The same facts in the social, economic, investment, and technical interpretation are confirmed in several foreign scientific works [16-21].

During the research, an impromptu network social survey was conducted, in which there were only two questions:

1. Are you ready to buy an affordable electric vehicle? $45 \%$ of respondents answered it positively.

2. Are you ready to buy an affordable electric car if you have specialized electric filling stations at least in your area of residence? This question was answered positively by $80 \%$ of the respondents. 
All these facts indicate that this type of transport is developing and being implemented, however, the issue of building electric filling stations, as an integral part of the infrastructure of a city or area, remains relevant and urgent.

\section{Methods}

When performing the calculations, the following methods were used:

- static data analysis methods;

- method for calculating the net present value of the project:

$$
N P V=\sum_{t=1}^{T} \frac{C_{t}}{(1+d)^{t}}-\sum_{t=1}^{T} \frac{I_{t}}{(1+d)^{t}}-I_{0},
$$

where $d$ - is a discounting rate;

$C_{t}-$ is a cash flow in the period $t$;

$I_{-} I_{t}-$ expenses in the period $t$;

$I_{-} I_{0}-$ initial investment in the project.

- graphical method for presenting the final results of the research.

\section{Results and discussion}

One of the most important problems in modern cities is that they are not ecologically friendly. At the same time, the use of vehicles causes great damage. The fuel used burns unevenly and incompletely: only $15 \%$ is spent on driving, and the remaining $85 \%$ pollutes the air. In this regard, there is a tendency to switch to electric transport all over the world.

The volume of the electric vehicle market in Russia at the end of 2019 amounted to 353 units, which is $145 \%$ more than in 2018 . The global figure is $0.7 \%$, which indicates a low demand for electric vehicles in Russia compared to global markets [22]. According to the Federal State Statistics Service of Russia [23], by the beginning of 2020, there was an increase in the number of electric vehicles by $75 \%$ compared to 2019 . The numbers speak for themselves. The Far East turned out to be the leader among the users of electric vehicles.

The main factors preventing the spread of electric vehicles in our country are: high cost, lack of charging infrastructure [24]. The inaccessibility of charging infrastructure in Russia does not allow the use of electric vehicles for long-distance travel.

We will carry out a feasibility study of the economic efficiency of the construction and operation of an electric filling station. Calculations include: justification of costs, planning of future income, a calculation based on these initial values of performance indicators.

Consider the initial investment costs at the construction stage. Calculation of the estimated cost of construction of an electric filling station includes: vertical layout; foundation for flagpole, stele; canopy (foundation); control room of an electric filling station of $60 \mathrm{~m} 2$ (assembly from panels); control room of an electric filling station with shop and cafe of $60 \mathrm{~m} 2$; transformer substation; ventilation and air conditioning; internal sewerage networks; internal water supply; external water supply networks; external sewerage networks; heating (heat-insulated floor); electrical part; lightning rods; grounding and lightning protection; boiler room; low-current networks; CCTV; security and fire alarm; fire extinguishers; outdoor electric lighting; road signs and road markings; improvement of the territory and landscaping; small architectural forms. The final estimated construction cost is presented in Table 1. 
Table 1. Estimated cost of construction of an electric filling station.

\begin{tabular}{|c|l|c|}
\hline No & \multicolumn{1}{|c|}{ Name } & Cost, thousand rubles \\
\hline 1 & Construction works & 10693.236 \\
\hline 2 & Installation work & 1176.52 \\
\hline 3 & Equipment & 2651.601 \\
\hline 4 & Total & 15121.73 \\
\hline
\end{tabular}

Source: calculated by the authors using the software program «Adept: Construction Management».

The total duration of construction depends on the length of certain types of work and amounted to 154 days in the period from 01.04.2021 to 01.11.2021. At the same time, the construction of an electric filling station can be divided into 3 stages: work in the filling area; construction of an electric filling station control room; other works (Table 2).

Table 2. Duration of construction.

\begin{tabular}{|c|l|c|}
\hline No & \multicolumn{1}{|c|}{ Name } & Duration, days \\
\hline 1 & Work in the filling area & 40 \\
\hline 2 & Construction of an electric filling station control room & 68 \\
\hline 3 & Other works & 77 \\
\hline
\end{tabular}

Source: calculated by the authors using the software program «Adept: Construction Management».

At the stage of operation of the constructed electric filling station, the cost of charging the battery is of great importance. [25]. It is determined by the minutes and depends on the capacity of the battery. One minute of charging costs 10-15 rubles. On average, it takes 1520 minutes to charge a $24 \mathrm{~kW} /$ hour battery. This charge will be used for approximately $150 \mathrm{~km}$. Table 3 shows the cost of one car battery charge up to $80 \%$ capacity.

Table 3. The cost of charging electric vehicles, rub.

\begin{tabular}{|c|l|c|c|}
\hline No & \multicolumn{1}{|c|}{ Name } & Battery capacity, $\mathrm{kW} / \mathrm{h}$ & Cost, rubles \\
\hline 1 & BMW i3 & 33 & 210 \\
\hline 2 & Nissan Leaf & 24 & 150 \\
\hline 3 & Mitsubishi i-MiEV & 22 & 138 \\
\hline 4 & Renault Twizy & 22 & 138 \\
\hline 5 & Tesla Model S & 75 & 460 \\
\hline 6 & Tesla Model X & 75 & 460 \\
\hline 7 & Lada Ellada & 23 & 145 \\
\hline
\end{tabular}

Source: calculated by the authors.

As you can see in Table 3, the highest charging cost is 460 rubles for Tesla Model S and Tesla Model X with a power reserve of about $380 \mathrm{~km}$. And the lowest cost for Mitsubishi iMiEV and Renault Twizy is only 138 rubles with a power reserve of about $130 \mathrm{~km}$.

At the stage of operation of the electric filling station under consideration, the costs of wages of maintenance personnel, costs of renting a land plot, current costs were taken into account (Table 4).

Table 4. Operating costs per year.

\begin{tabular}{|c|l|c|}
\hline No & \multicolumn{1}{|c|}{ Name } & Cost, rubles \\
\hline 1 & Wage & 3138882 \\
\hline 2 & Land lease & 55400 \\
\hline 3 & Insurance & 151210 \\
\hline 4 & Utility bills & 172800 \\
\hline
\end{tabular}

Source: calculated by the authors.

After justifying the costs and revenues at the stage of construction and operation of an electric filling station, taking into account environmental safety [26], efficiency indicators were calculated taking into account an annual discount rate of $15 \%$ (Table 5). 
Table 5. Efficiency indicators of total investment costs.

\begin{tabular}{|c|l|c|}
\hline No & \multicolumn{1}{|c|}{ Name } & Value \\
\hline 1 & Annual discount rate & $15 \%$ \\
\hline 2 & Net present value (NPV) & 181952571 rub. \\
\hline 3 & Discounted payback period & 4.58 years \\
\hline
\end{tabular}

Source: calculation tables from a software program «Alt-Invest. Construction» (calculated by the authors).

As you can see in Fig., the discounted payback period will increase to 8.78 years if the amount of energy consumed is decreased by 1.4 times.

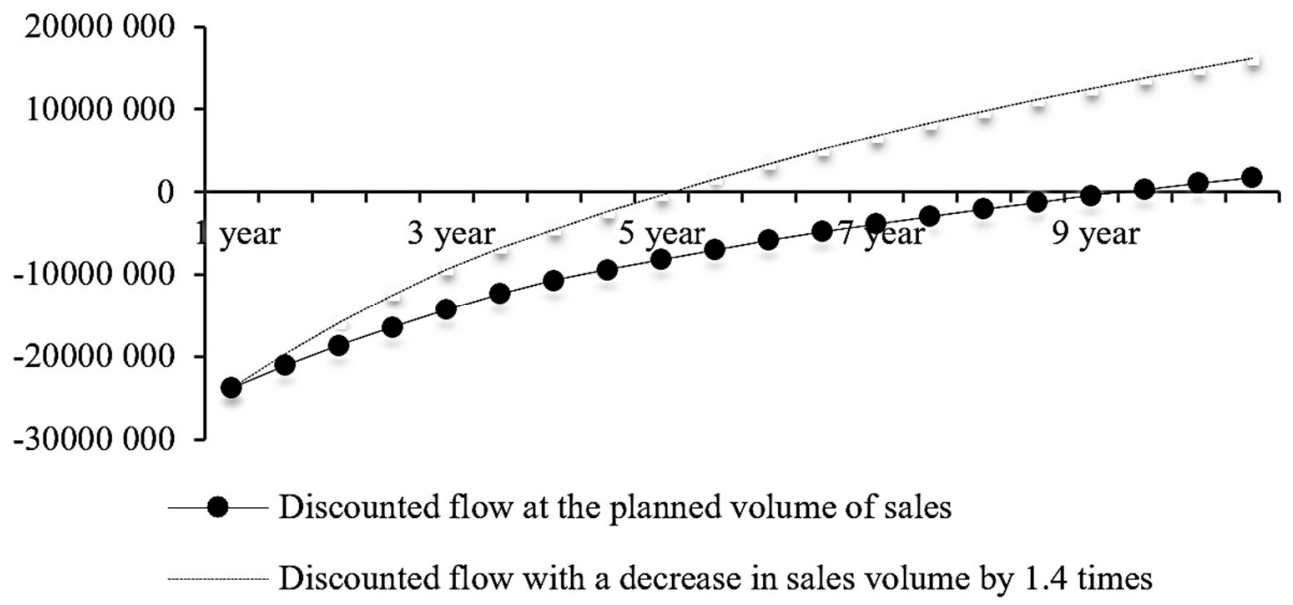

Fig. Discounted payback period.

\section{Conclusions}

In this work, an economic efficiency justification of the construction and operation of electric filling stations (territorial location in Russia) was carried out. The necessary costs include the cost of electric filling and transformer substation, purchase of the necessary equipment. In the process of operation, the costs of wages of the working personnel, the current costs of utilities for the construction of the electric filling station during 9 years of operation were taken into account.

Calculations have shown that the operation of the electric filling station will be efficient with an annual energy consumption of 2,073,600 $\mathrm{kWh}$. A decrease in consumption by 1.4 times can lead to the fact that the payback period of the project will increase by 4.2 years and will amount to 8.78 years.

The results of the research are of interest to drivers, because the automotive market is growing, and the economic and environmental component is increasingly giving impetus to the development of electric vehicles as a public transport, which is receiving great attention all over the world. To expand the possibilities of using electric vehicles, the infrastructure component should be thought out in the form of service stations and electric filling stations (in free territorial access). Also, this study will be interesting from the point of view of the investment component. Since the construction of electric filling stations is an economically attractive niche, taking into account the global trends of the increasingly dynamically developing segment of electric vehicles as an ecological transport. 


\section{References}

1. K. Degirmenci, H. Michael Breitner. Consumer purchase intentions for electric vehicles: is green more important than price and range, Transportation Research Part D 51, 250260 (2017). DOI: 10.1016/j.trd.2017.01.001.

2. A.C. Mersky, F. Sprei, C. Samaras, Z. Qian. Effectiveness of incentives on electric vehicle adoption in Norway Transportation Research Part D 46, 56-68 (2016). DOI: 10.1016/j.trd.2016.03.011.

3. J. Yang, J. Dong, L. Hu. A data-driven optimization-based approach for siting and sizing of electric taxi charging stations Transportation Research Part C 77, $462-477$ (2017). DOI: 10.1016/j.trc.2017.02.014.

4. R. Iacobucci, B. McLellan, T. Tezuka. Modeling shared autonomous electric vehicles: potential for transport and power grid integration Energy 158, 148-163 (2018). DOI: 10.1016/j.energy.2018.06.024.

5. G. Ala, G.D. Filippo, F. Viola, G. Giglia, A. Imburgia, P. Romano, V. Castiglia, F. Pellitteri, G. Schettino, R. Miceli. Different scenarios of electric mobility: current situation and possible future developments of fuel cell vehicles in Italy Sustainability 12, 564 (2020). DOI: $10.3390 /$ su12020564.

6. C.W. Hsu, K. Fingerman. Public electric vehicle charger access disparities across race and income in California. Transport Policy 100, 59-67 (2021). DOI: 10.1016/j.tranpol.2020.10.003.

7. T.T. Simon, D.J. Brian, J.M. Huya-Kouadiob, C. Houchinsb, D.A. DeSantisb, R. Ahluwaliac, A.R. Wilsona, G. Kleend, D. Papageorgopoulosa. Direct hydrogen fuel cell electric vehicle cost analysis: system and highvolume manufacturing description, validation and outlook Journal of power sources 399, 304-313 (2018) DOI: 10.1016/j.jpowsour.2018. 07.100.

8. Q. Xu, J. Huang, Y. Han, Y. Yang, L. Luo L. A study on electric vehicles participating in the load regulation of urban complexes Energies 13 (11), 2339 (2020) DOI: 10.3390/en13112939.

9. A. Ajanovic, A. Glatt. Wirtschaftliche und ökologische aspekte der elektromobilität Elektrotechnik and informationstechnik 137/4-5, 136-146 (2020). DOI: 10.1007/s00502020-00812-x.

10. K. Seddig, P. Jochem, W. Fichtner. Integrating renewable energy sources by electric vehicle fleets under uncertainty Energy 141, 2145-2153 (2017). DOI: 10.1016/j.energy. 2017.11.140.

11.F. Triel, T.E. Lipman. Modeling the future California electricity grid and renewable energy integration with electric vehicles Energies 13, 5277 (2020). DOI: 10.3390/ en13205277.

12. J. Zhu, Z. Yang, Y. Guo, J. Zhang, H. Yang. Short-term load forecasting for electric vehicle charging stations based on deep learning approaches, Applied sciences 9, 1723 (2019). DOI: 10.3390/app9091723.

13. X. Sun, Z. Li, X. Wang, C. Li. Technology development of electric vehicles: a review Energies 13, 90 (2019). DOI: 10.3390/en13010090.

14. A. Mielea, J. Axsena, M. Wolinetza, E. Mainec, Z. Longa. The role of charging and refueling infrastructure in supporting zero-emission vehicle sales, Transportation Research Part D 81, (2020). DOI: 10.1016/j.trd.2020.102275.

15. K. Tucki, O. Orynycz, A. Swi'c, M. Mitoraj-Wojtanek. The development of electromobility in Poland and EU States as a tool for management of $\mathrm{CO}_{2}$ emissions. Energies 12, 2942 (2019). DOI: 10.3390/en12152942. 
16. T. Gnanna, S. Funkea, N. Jakobssonb, P. Plötza, F. Spreib, A. Bennehag. Fast charging infrastructure for electric vehicles: today's situation and future needs 62, 314-329 (2018). DOI: 10.1016/j.trd.2018.03.004.

17. M. Kama, W. Sarkb, F. Alkemade. Multiple roads ahead: how charging behavior can guide charging infrastructure roll-out policy, Transportation Research Part D, 85 (2020). DOI: $10.1016 /$ j.trd.2020.102452.

18. F. Orsi. On the sustainability of electric vehicles: what about their impacts on land use? Sutainable cities and society 66, (2021). DOI: 10.1016/j.scs.2020.102680.

19. Z. Chena, F. He, Y. Yin. Optimal deployment of charging lanes for electric vehicles in transportation networks, Transportation Research Part B 91, 344-365 (2016). DOI: 10.1016/j.trb.2016.05.018.

20. M.H. Amini, O. Karabasoglu. Optimal operation of interdependent power systems and electrified transportation networks, Energies 11, 196 (2018). DOI: 10.3390/en11010196.

21. T. Thananusak, P. Punnakitikashem, S. Tanthasith, B. Kongarchapatara. The development of electric vehicle charging stations in thailand: policies, players, and key issues, World Electr. Veh. J. 12, 2 (2021). DOI: 10.3390/wevj12010002.

22. M.V. Komarova. Analysis of the electric vehicle market in Russia Innovations, The science. Education 21, 276-281 (2020).

23. E.S. Rahmatullina, I.V. Morchkova. Developing a strategy for petrol station development, Proceedings of the international scientific and practical conference «Intelligent city: sustainability, management, architecture, renovation, technologies», 324-330 (2018).

24.D.A. Rybnikov. Charging infrastructure development: a reasonable balance, Development vector 6, 51 (2018).

25. A.L. Bolsherotov. Methodological foundations for assessing the environmental safety of construction in urbanized areas, News of the KSUAE 2, 222 (2020). 